\title{
REVIEW BUKU : THE ART OF INTEGRATIVE COUNSELING Sigit Sanyata ${ }^{1}$
}

\section{PENDAHULUAN}

The art of integrative konseling dirancang sebagai sebuah buku tambahan untuk mereka yang sudah memiliki program dasar dalam konseling teori dan praktek. Kecuali Anda memiliki kursus teori konseling atau memiliki setidaknya membaca buku teks standar yang mencakup berbagai teori konseling, Anda mungkin mengalami kesulitan untuk memahami dan menerapkan ide-ide dalam buku ini. Buku ini tidak dirancang sebagai pengganti teori konseling teks survey. Sebaliknya, terutama ditujukan untuk program lanjutan dalam praktek konseling, teknik konseling dan prosedur terapeutik. Saya mengasumsikan bahwa Anda sudah terbiasa dengan konsep dasar yang berhubungan dengan beberapa sistem teoritis utama yang mendasari praktek konseling, seperti terapi psikoanalitik, terapi Adlerian, terapi eksistensial, orang-terapi berpusat, terapi Gestalt, psikodrama, terapi redecision, terapi realitas, terapi perilaku, terapi perilaku kognitif, terapi singkat solusi-fokus, terapi naratif, terapi feminis, dan keluarga.

Dalam buku ini Gerald Corey berusaha untuk melakukan beberapa hal:

1. Menjelaskan konsep dan teknik yang paling menarik dalam pendekatan integrative dalam berlatih konseling,

2. Menunujukkan bagaimana konsep dan teknik bisa dipinjam dari berbagai model teoritis dan diterapkan pada proses konseling dari awal untuk tahap terminasi melalui diskusi tentang pekerjaan dengan seorang klien tunggal,

3. Menyarankan cara untuk berpikir tentang merancang pendekatan integrative konsep sendiri yang akan menjadi landasan untuk apa yang Anda lakukan dalam praktik konseling Anda.

Pendekatan integratif untuk konseling dan psikoterapi yang terbaik ditandai dengan upaya untuk melampaui dan dalam pendekatan sekolah unik untuk melihat apa yang dapat dipelajari, dan bagaimana pelanggan dapat memperoleh manfaat dari perspektif lain ( Arkowitz, 1997). Konseling Integratif adalah proses pemilihan konsep dan metode dalam berbagai sistem. Pendekatan integratif mungkin idealnya sebuah sintesis kreatif kontribusi unik dari orientasi teoritis yang berbeda, secara dinamis mengintegrasikan konsep dan teknik yang memenuhi kepribadian unik dan gaya praktisi. Sejak awal 1980-an, psikoterapi ditandai dengan gerakan cepat menuju integrasi. Gerakan ini didasarkan pada penggabungan yang terbaik dari orientasi yang berbeda sehingga model teoritis yang lebih lengkap dapat diartikulasikan dan pengobatan yang lebih efektif dikembangkan (Goldfried \& Castonguay, 1992). Masyarakat untuk Eksplorasi Psikoterapi Integrasi adalah organisasi internasional yang didirikan pada tahun 1983. Para anggotanya adalah para profesional yang bekerja pada pengembangan pendekatan terapi yang melampaui orientasi teoretis yang unik. Salah satu alasan

\footnotetext{
${ }^{1}$ Mahasiswa Program Doktoral Universitas Pendidikan Indonesia
} 
kecenderungan integrasi psikoterapi adalah pengakuan bahwa tidak ada teori tunggal yang cukup komprehensif untuk mencerminkan kompleksitas perilaku manusia, terutama ketika berbagai jenis pelanggan dan masalah-masalah khusus mereka dipertimbangkan. Karena ada teori yang memiliki paten atas kebenaran, dan tidak ada sekumpulan saran teknis selalu efektif dalam bekerja dengan populasi klien beragam, beberapa penulis percaya bahwa itu masuk akal untuk menyeberangi perbatasan dengan mengembangkan integratif sebagai dasar untuk praktek orientasi ke depan (Lazarus, 1996).

Banyak terapis didefinisikan sebagai "eklektik", dan kategori ini mencakup berbagai praktek. Mungkin prakteknya terburuk, adalah sebuah koleksi eklektik teknis acak tanpa ada pembenaran teoritis seluruh. Sinkretisme, di mana praktisi, kurangnya pengetahuan dan keterampilan dalam pemilihan intervensi, untuk mengekstrak semua yang tampaknya bekerja, hal itu disebut sering membuat tidak berusaha untuk menentukan apakah prosedur terapi memang efektif. Seperti campuran adalah yang terbaik sebuah ortodoksi sempit dan dogmatis. Menggambar teknik dari berbagai sumber tanpa alasan yang kuat hanya dapat menyebabkan kebingungan sinkretis (Lazarus, 1986, 1996, Lazarus, Beutler, \& Norcross, 1992).

Ada beberapa cara untuk mencapai suatu pendekatan integratif untuk praktik konseling. Tiga paling umum adalah eklektisisme teknis, integrasi teoritis dan faktor umum (Arkowitz, 1997). eklektisisme Teknis cenderung untuk fokus pada perbedaan, memilih banyak pendekatan dan adalah seperangkat teknik. Jalan ini panggilan untuk penggunaan teknik dari sekolah yang berbeda tanpa harus berlangganan ke posisi teoritis yang melahirkan mereka. Namun, integrasi teoritis mengacu pada penciptaan konseptual atau teoritis di luar campuran sederhana teknik.

Jalur ini dimaksudkan untuk menghasilkan suatu kerangka konseptual yang memadukan yang terbaik dari dua atau lebih pendekatan teoretis asumsi bahwa hasilnya akan lebih kaya daripada teori sendiri (Norcross
\& Newman, 1992). Pendekatan ini mencoba untuk menemukan faktor umum di seluruh sistem teoritis yang berbeda dalam mencari elemen umum. Walaupun ada perbedaan antara teori, Itu adalah inti dikenali konseling terdiri dari variabel non-spesifik yang umum untuk semua perlakuan. Perspektif pada integrasi didasarkan pada asumsi bahwa faktor-faktor umum adalah setidaknya sama penting dalam akuntansi untuk hasil terapi sebagai faktor tunggal yang membedakan teori dari yang lain.

Meskipun ada keuntungan untuk mengintegrasikan berbagai teknik dari beberapa teori yang berbeda, juga memungkinkan untuk menggabungkan beberapa prinsip kunci dan konsep-konsep dari berbagai orientasi teoritis. Ada beberapa konsep pendekatan pengalaman yang sangat mungkin juga pendekatan campuran cognitive behavioral. Sebagai contoh, pendekatan pengalaman menekankan di sini dan sekarang kesadaran, hubungan terapeutik dan mengeksplorasi perasaan - semua konsep yang dapat dimasukkan ke dalam terapi berorientasi pada tindakan. Pelanggan dapat meminta untuk memutuskan apa yang mereka ingin lakukan penjangkauan ini, termasuk rencana untuk perubahan perilaku. Semua tindakan pengobatan berorientasi tergantung pada hubungan baik antara klien dan terapis (Erskine \& Moursund, 2004). Teknik tidak mengambil root jika tidak ada hubungan kerja yang baik, dan pelanggan lebih mungkin untuk bekerja sama dengan intervensi kognitif dan perilaku seorang terapis jika mereka merasa bahwa terapis yang benar-benar tertarik pada kesejahteraan mereka .

Arnold Lazarus (1997), pendiri terapi multimodal, menganut eklektisisme teknis (atau sistematis). teknik Terapis multimodal meminjam banyak sistem perawatan lainnya yang telah dibuktikan efektif dalam menangani masalah spesifik. Lazarus menimbulkan kekhawatiran tentang teori eklektik karena ia percaya bahwa campuran potongan berbagai teori kemungkinan untuk mengaburkan masalah. Dia berpendapat bahwa dengan tetap konsisten praktisi secara teoritis tapi secara teknis eklektik bisa mengeja akurat 
apa intervensi yang akan digunakan dengan berbagai klien, dan cara-cara yang mereka pilih prosedur tersebut.

Eklektisisme teknis sangat diperlukan untuk bekerja dengan berbagai latar belakang budaya. Kerusakan dapat berasal dari pelanggan yang diharapkan untuk memenuhi semua spesifikasi dari sebuah teori yang diberikan, apakah nilai-nilai yang dianut oleh teori konsisten dengan nilai-nilai budaya mereka sendiri. Alih-alih memperluas pelanggan untuk menyesuaikan ukuran sebuah teori tunggal, praktisi ditantang untuk menyesuaikan teori dan praktek untuk memenuhi kebutuhan unik dari klien. Persyaratan ini panggilan untuk konselor memiliki pengetahuan berbagai budaya, sadar akan warisan budaya mereka dan memiliki keterampilan untuk membantu berbagai klien untuk menghadapi realitas budaya mereka.

Sebuah studi merangkum pentingnya memperhitungkan keragaman budaya dan tren masa depan dalam praktek psikoterapi, "adalah tantangan besar untuk bidang psikoterapi untuk menemukan cara-cara kreatif untuk mengintegrasikan nilai-nilai dan visi dunia beberapa budaya dalam wacana efisiensi dan bukti yang saat ini mendominasi pelayanan kesehatan "(Norcross, Hedges, \& Prochaska, 2002, hal 322).

Praktisi yang terbuka ke jalur integratif memandang akan menemukan bahwa beberapa teori memainkan peran penting dalam pendekatan mereka untuk konseling pribadi. Setiap teori memiliki kontribusi unik dan bidang keahlian sendiri. Menerima bahwa teori masing-masing memiliki kekuatan dan kelemahan dan adalah dengan definisi "berbeda" dari lainnya, praktisi memiliki dasar untuk mulai mengembangkan sebuah teori yang cocok untuk mereka. Penting untuk dicatat bahwa, kecuali jika konsultan memiliki pengetahuan menyeluruh dan akurat teori, mereka dapat membuat sintesis benar. Secara singkat, praktisi dapat mengintegrasikan apa yang mereka tidak tahu (Norcross \& Newman, 1992). Tantangan bagi konselor untuk berpikir dan berlatih secara penuh, namun kritis. Pengembangan perspektif integratif adalah upaya berkesinambungan yang disempurnakan dengan pengalaman.

\section{Mencari Penyebut Yang Umum Di Sekolah Terapi}

Pendekatan Experiential (seperti terapi eksistensial dan terapi gestalt) tempat premium pada menjelajahi perasaan dalam proses terapeutik. Namun, konsep bekerja dengan perasaan pasti bisa terkait erat dengan kebutuhan untuk mengeksplorasi pikiran dan perilaku yang terkait dengan perasaan ini. Sebuah eklektisisme sistematis berdasarkan mencari penyebut yang umum yang melampaui orientasi terapeutik, yaitu untuk mengidentifikasi konsep-konsep kunci yang berbagi berbagai teori atau konsep yang bisa berguna dikombinasikan.

Namun, seperti Lazarus (1997) memperingatkan, campuran konstruk teoritis lebih sulit daripada menggunakan teknik yang berbeda dari sekolah yang berbeda. Praktisi yang mencoba untuk berbaur konstruksi teoritis orientasi yang berbeda dalam model integratif sendiri mereka harus menentukan bahwa konsep ini memang kompatibel. Dalam mencoba untuk mencampur bersama kerangka teoritis yang berbeda, adalah penting bahwa kerangka kerja ini setuju untuk merger sukses.

\section{Manfaat Integrasi}

Karena manusia yang terintegrasi, pendekatan integratif untuk praktik konseling berfokus pada pikiran, perasaan dan bertindak. kompetensi konseling yang efektif adalah kombinasi dari teknik kognitif, emosi dan perilaku. Kombinasi tersebut dibutuhkan untuk membantu klien berpikir tentang kepercayaan mereka dan asumsi, mengalami tingkat perasaan konflik mereka dan perjuangan dan membawa pengetahuan ke dalam program aksi dengan berperilaku baru pola kehidupan sehari-hari.

Preston (1998) berpendapat bahwa 
tidak ada model teoretis tidak dapat memenuhi berbagai masalah klien hadir dalam terapi. Dia mengatakan bahwa sangat penting bagi terapis untuk memiliki pemahaman dasar model berbagai terapi bagi mereka untuk memiliki sejumlah strategi intervensi. Baginya, masalah penilaian adalah penting, "Apa orang ini yang membutuhkan khususnya untuk menderita kurang, untuk menyembuhkan, tumbuh dan mengatasinya lebih efektif? Preston merekomendasikan bahwa pemilihan praktisi, intervensi harus dipandu oleh penilaian mereka terhadap klien. Hal ini meminjamkan bobot gagasan mengintegrasikan evaluasi dengan pengobatan. Setelah dokter yang tahu apa masalah pelanggan sasaran dan tujuan, adalah bijaksana untuk mengembangkan teknik tertentu yang disesuaikan dengan klien.

\section{Keterbatasan Pendekatan Integrative}

Ada beberapa kelemahan untuk mendorong pengembangan model integratif, sebagai lawan terutama bergaul dengan teori. Pendekatan eklektik yang tidak disiplin dapat menjadi alasan untuk tidak mengembangkan justifikasi yang kuat untuk secara sistematis mengikuti konsep dan teknik yang ekstensi mereka sendiri. Jika penasihat memilih hanya ragam, ada kemungkinan bahwa mereka memilih harus menjadi ekspresi prasangka dan praduga. Hal ini penting untuk menghindari jebakan dengan campuran dari teori-teori baru unamalgamated naik buru-buru bersama-sama.

\section{Menggambar Tentang Teknik Dari Berbagai Model Teoritis}

Bagi para praktisi untuk memberitahu memulai, adalah logis untuk memilih teori utama adalah yang terdekat dengan keyakinan inti mereka. Hal ini penting untuk mempelajari teori selengkap mungkin dan pada saat yang sama terbuka untuk mengeksplorasi cara menggambarpada teknik dariteoriyang berbeda. Mulai bekerja dalam parameter teori tunggal, praktisi memiliki titik jangkar dari mana untuk membangun perspektif nasihat mereka sendiri. Namun, hanya dengan mengikuti sebuah teori tidak menyiratkan bahwa seorang praktisi primer dapat menerapkan teknik yang sama untuk semua pelanggan. Hal ini penting untuk menjadi fleksibel dalam bagaimana teknik di atas diaplikasikan untuk berbagai macam klien.

Pada topik fleksibilitas terapi, Paul (1967) adalah relevan: "apa pengobatan, oleh siapa, paling efektif untuk itu individu dengan masalah tertentu dan di bawah apa yang membuat keadaan? "Terlepas dari model ini dapat bekerja dengan dokter, mereka harus menentukan teknik, prosedur atau metode intervensi untuk digunakan, kapan menggunakan mereka dan dengan klien.

Hal ini berguna untuk dokter untuk menghindari menjadi permainan favorit digabungkan dengan teknik mereka menerapkan secara acak kepada seluruh pelanggan, terlepas dari asal-usul budaya mereka. Nasihat untuk menjadi efektif, maka perlu menggunakan teknik dan prosedur dengan cara yang konsisten dengan nilai-nilai klien, pengalaman hidup dan latar belakang budaya. Meskipun tidak bijaksana untuk klien stereotip karena warisan budaya mereka, hal ini berguna untuk menilai bagaimana konteks budaya memiliki dampak pada masalah mereka. Beberapa teknik dapat kontra-ditunjukkan karena sosialisasi klien. Dengan demikian, respon pelanggan (atau tidak) teknik tertentu merupakan barometer penting untuk mengukur efektivitas metode ini.

\section{Dasar penulis Pendekatan Integratif}

$$
\text { Pada bagian akhir artikel ini, }
$$
penulis menyajikan beberapa elemen dari pendekatan integratif untuk konseling dengan menggambarkan terapi eksistensial sebagai landasan pendekatannya. Penulis menunjukkan bagaimana ia menarik konsep-konsep dan teknik dari orientasi teoretis lain untuk memperluas pendekatan integratif tersebut. Teori yang paling mendekati pandangan dunia penulis, dan ini berfungsi sebagai dasar untuk pembangunan orientasi teoretisnya adalah terapi eksistensial. Selain pendekatan eksistensial, dua teori terkait yang menggunakan banyak 
penulis terapi Gestalt dan psychodrama.

Setelah menjelaskan secara singkat beberapa konsep kunci dan tema dari orientasi eksistensial, Gestalt dan psychodrama, penulis ini menunjukkan bagaimana menggabungkan konsep-konsep dasar dan teknik dari sejumlah perawatan berorientasi aksi lainnya: Adlerian Terapi, realitas terapi, terapi perilaku, terapi rasional emotif, terapi kognitif dan terapi feminis. Untuk diskusi tentang bagaimana semua pendekatan di atas berlaku untuk kasus tunggal, lihat Corey Kasus (2001b) pendekatan untuk konseling dan psikoterapi.

\section{Terapi Eksistensial Sebagai Dasar Filosofis}

Memiliki orientasi filosofis dari penulis sangat dipengaruhi oleh pendekatan eksistensial, yang conceives konseling sebagai proses mengubah hidup. Konseling dapat dilihat sebagai suatu perjalanan di mana terapis adalah panduan yang memfasilitasi eksplorasi klien. Ada beberapa tema kunci pendekatan eksistensial yang tampaknya penulis untuk menangkap esensi dari upaya terapeutik. Menurut pandangan eksistensialis, manusia mampu kesadaran diri, yang merupakan kapasitas yang berbeda yang memungkinkan orang untuk berpikir dan memutuskan. Dengan kesadaran orang untuk menjadi makhluk bebas yang bertanggung jawab untuk memilih cara mereka hidup.

Penekanan pada kebebasan dan tanggung jawab merupakan pusat latihan, konsep ini memungkinkan orang untuk merancang ulang hidup mereka. Pilihan menimbulkan kecemasan, yang merupakan karakteristik dasar manusia. Kekhawatiran ini memuncak ketika orang mencerminkan pada kenyataan bahwa mereka akan mati. Dihadapkan dengan prospek tak terelakkan dari kematian memberikan makna yang mungkin saat itu. Realitas kematian adalah sebuah katalis yang dapat menyebabkan penciptaan kehidupan yang memiliki arti dan tujuan. Manusia berusaha menuju penataan tujuan dan nilai-nilai yang memberi arti bagi kehidupan, yang dikembangkan melalui komitmen untuk kebebasan dan untuk membuat pilihan berurusan dengan ketidakpastian.

Baik terapi eksistensial dan orangberpusat tempat pusat terapi terkenal pada hubungan orang-ke-orang. Hal ini diasumsikan bahwa pertumbuhan terjadi melalui pertemuan klien asli. Penekanan pada kualitas manusia dari konseling hubungan terapeutik untuk mengurangi kemungkinan membuat proses mekanis. Dalam berpikir tentang terapi dari perspektif eksistensial, teknik ini selalu penting sekunder. Dari perspektif eksistensial, itu bukan praktisi menggunakan teknik yang membuat perbedaan dalam terapi, tetapi kualitas hubungan dengan klien yang menyembuhkan. Bunga menjadi terapis adalah sepenuhnya hadir untuk klien mungkin, membangun hubungan kepercayaan, dan pindah ke dunia subjektif klien. Jika klien bisa merasakan kehadiran terapis dan keinginan untuk membuat sambungan nyata, maka dasar yang kokoh sedang diciptakan untuk kerja keras yang membutuhkan konseling.

Karena pendekatan eksistensial terutama menyangkut isu-isu seperti sasaran terapi, kondisi dasar eksistensi manusia dan terapi sebagai perjalanan bersama, praktisi yang tidak terikat oleh seperangkat teknik tertentu. Bahkan jika mereka dapat menggabungkan berbagai teknik dari orientasi lain, tindakan mereka dipandu oleh kerangka filosofis tentang makna eksistensi manusia. Pandangan eksistensial menyediakan praktisi dengan kerangka untuk memahami masalah manusia yang universal, termasuk wajah dan menangani: masalah kebebasan pribadi, selfalienation dan dengan orang lain. takut kematian dan ketidakberadaan. Hidup dengan keberanian. Jelajahi makna kehidupan. dan membuat pilihan kritis.

Terapi Eksistensial bukan model konseling yang berbeda atau terorganisir dengan baik. Bahkan, para pendiri terapi eksistensial tidak bertujuan untuk menciptakan lingkungan sekolah yang terpisah dari terapi, 
melainkan bahwa konsep-konsep kunci dan tema bisa diintegrasikan di semua sekolah terapi (Mei \& Yalom, 2000). Bugental dan Bracke (1992) mempertimbangkan kemungkinan integrasi kreatif dari proposal konseptual terapi eksistensial dengan pendekatan psikodinamik atau kognitif. Mereka berpendapat bahwa dokter mengalami kontras orientasi sering menerima konsep eksistensial dan dengan demikian secara implisit untuk beroperasi dalam kerangka eksistensial.

\section{Gestalt Terapi; Perspektif Holistik}

Terapi Gestalt adalah benar-benar suatu orientasi integratif dalam bahwa ia berfokus pada apa yang ada di kesadaran klien. Dari perspektif Gestalt, perasaan, pikiran, tubuh sensasi dan tindakan semua akan digunakan sebagai panduan untuk memahami apa yang penting bagi klien dalam setiap saat. Sentralitas dari apa yang dalam kesadaran adalah klien yang ideal untuk memahami dunia klien. Seorang terapis Gestalt pendekatan klien tanpa satu set sebelumnya dari bias atau agenda yang ditetapkan. Sebaliknya, penekanan ditempatkan pada apa yang terjadi dengan fenomenologi klien. Dengan memperhatikan untuk memimpin jelas verbal dan nonverbal yang diberikan, terapis memiliki titik awal untuk menjelajahi dunia klien.

Beroperasi dalam kerangka Gestalt, penulis ini melihat tujuan utamanya untuk meningkatkan kesadaran pelanggan "apa yang ada." Perubahan kesadaran bahwa klien mengetahui waktu belum. Kendala dari pendekatan ini memiliki kesadaran dan kualitas kontak antara individu dan lingkungan.

Pendekatan Gestalt ini ditandai dengan beberapa konsep kunci yang dapat dicampur berbuah di arah lain. Gestalt Terapi (dan psikodrama) teknik memungkinkan klien dengan cara-cara untuk membawa kembali kenangan menyakitkan dan perasaan yang berkaitan dengan peristiwa masa lalu dan hadir di TKP. Melalui penggunaan terampil dan sensitif intervensi terapi Gestalt, adalah

Insight : Jurnal Bimbingan Konseling Volume 5(2) mungkin untuk membantu pelanggan fokus pada kesadaran mereka sekarang dari apa yang mereka pikirkan dan rasakan dan apa yang mereka lakukan. Klien disediakan dengan berbagai alat, sebagai pengalaman Gestalt, untuk membuat keputusan tentang mengubah jalan hidup.

Gestalt Therapy adalah pendekatan kreatif yang menggunakan pengalaman mengambil klien untuk berbicara dengan tindakan dan pengalaman. Ini adalah sudut pandang terhadap pertumbuhan dan perbaikan, bukan hanya sebuah sistem teknik untuk mengobati gangguan. Dengan penekanan pada hubungan antara klien dan terapis, ada semangat menyarankan kreatif, menciptakan dan melakukan percobaan yang dirancang untuk meningkatkan kesadaran.

\section{Psikodrama Pendekatan Integratif}

Meskipun psikodrama terutama digunakan dalam terapi kelompok, psikodrama banyak teknik yang dapat digunakan dalam konseling sukses. Psikodrama adalah sebuah pendekatan di mana klien bertindak menggambarkan peran masa lalu, sekarang atau diantisipasi dan situasi kehidupan. Hal ini dilakukan untuk mencoba memahami lebih dalam, mengeksplorasi perasaan dan mendapatkan pelepasan emosional dan mengembangkan keterampilan perilaku. peristiwa penting yang diambil untuk membantu klien berhubungan dengan perasaan yang tidak diakui dan terpendam, untuk menyediakan saluran bagi ekspresi penuh perasaan dan sikap dan untuk memperluas repertoar peran.

\section{Behavior Therapy}

Diintegrasikan ke sistem lain seperti pendekatan psikodinamik perilaku, pengalaman, dan kognitif - psikodrama menawarkan lebih pengalaman, menambahkan gambar, aksi dan pertemuan interpersonal langsung. Pada gilirannya, psikodrama dapat menggunakan metode dari pendekatan lain untuk pendekatan pengalaman dan kognitif dan perilaku, pelanggan tanah dalam proses yang 
berarti.

Menurut Blatner (1996), kontribusi penting psikodrama adalah bahwa hal itu mendukung tren eklektisisme teknis dalam psikoterapi. Praktisi ditantang untuk menggambar pada alat akan berguna dalam situasi tertentu. Namun psikodrama yang terbaik adalah dipandang sebagai satu set alat opsional, daripada pendekatan tunggal untuk semua klien (Blatner, 1996). Psikodrama menggunakan sejumlah teknik-teknik khusus untuk mengintensifkan perasaan, menjelaskan keyakinan implisit, meningkatkan kesadaran diri dan perilaku praktek baru. Salah satu alat yang paling kuat dari psikodrama adalah peran pembalikan, yang melibatkan klien mengambil bagian dalam orang lain. Terima kasih untuk membalikkan peran dengan orang penting, klien mampu membuat ide-ide kognitif dan emosional signifikan dalam partainya dalam suatu hubungan. Teknik ini juga menciptakan empati untuk posisi orang lain. Peran dan bermain variasi pembalikan peran memiliki banyak kegunaan dalam-orang dan konseling kelompok. Beberapa teknik lain dari psikodrama yang praktisi dapat menggunakan meliputi presentasi sendiri, solilokui, pelatihan, pemodelan, peran-pelatihan, latihan perilaku dan proyeksi masa depan.

Jelas bahwa banyak teknik yang dapat disesuaikan agar sesuai dengan baik dalam kerangka model teoritis lainnya kontemporer, termasuk terapi psikoanalitik, terapi perilaku, terapi multimodal, terapi Gestalt, terapi Adlerian, terapi bermain, imajinasi terapi, Jung terapi, terapi keluarga Psychodramatic, dan kelompok terapi. Menurut Blatner (1997), nilai psikodrama terletak pada kenyataan bahwa metodologi dapat diintegrasikan dengan perlakuan lain pendekatan daripada bertindak dalam terlihat persaingan. [Lihat Blatner (1996) dan Corey (2004, Bab 8) untuk psikodrama diskusi diterapkan untuk konseling kelompok.]

Menggambar Pada Tindakan Terapi Yang Berorientasi sama dengan domain afektif, yang dianggap penting untuk mengintegrasikan konsep dan teknik pendekatan berorientasi aksi sebagai cara untuk melakukan perubahan dan perilaku kognitif. Berikut ini adalah beberapa cara yang penulis menggunakan terapi berorientasi pada tindakan (perilaku, terapi multimodal, terapi kognitif-perilaku, terapi realitas, terapi Adlerian dan terapi feminis) dalam modelnya integrasi. Untuk penjelasan rinci tentang bagaimana pendekatan pragmatis diterapkan untuk kasus tunggal, lihat Corey Kasus (2001b) pendekatan untuk konseling dan psikoterapi.

Sebuah asumsi dasar dari perspektif perilaku adalah bahwa kognisi yang paling bermasalah, emosi, dan perilaku yang telah dipelajari dan yang belajar baru bisa memodifikasi mereka. Meskipun proses modifikasi ini sering disebut sebagai "terapi," adalah pengalaman pendidikan lebih benar di mana individu yang terlibat dalam pengajaran / proses pembelajaran. Ada banyak kesamaan antara konseling dan pendidikan. Konseling adalah pendidikan di bahwa orang mengembangkan sebuah perspektif baru tentang cara belajar, dan mereka juga mencoba cara yang lebih efektif untuk mengubah kognisi mereka, emosi, dan perilaku. Banyak teknik yang digunakan oleh pendekatan berorientasi aksi lainnya, dengan perilaku inti yang kuat (seperti terapi perilaku rasional emotif, terapi kognitif, terapi realitas, dan terapi feminis), asumsi saham ini dasar dari konseling sebagai proses pendidikan, dan mereka menekankan pengajaran / pembelajaran aspek dari proses konseling. Teknis pendekatan berorientasi aksi dapat digunakan untuk mencapai tujuan terapi humanistik yang mencirikan pengalaman. Jelas bahwa jembatan dapat menghubungkan terapi pengalaman dan perilaku.

\section{Multimodal Therapy}

Multimodal terapi-cabang dari terapi perilaku adalah komprehensif, sistematis, pendekatan holistik untuk terapi perilaku yang dikembangkan oleh Arnold Lazarus (, 
1989,1995 1997). Pondasi dari latihan pada teori pembelajaran sosial, Lazarus mendukung gambar teknis hampir semua model terapi. Dalam model integratif nya, teknik baru terus diperkenalkan dan teknik yang ada halus, tetapi mereka tidak pernah menggunakan senapan (Lazarus, 1992; Lazarus \& Beutler, 1993).

Dengan menggunakan pendekatan multimodal, praktisi dapat berfungsi secara aktif dan directively dengan menyediakan informasi dan instruksi. Hal ini memerlukan penyesuaian konstan teknik terapi untuk mencapai tujuan klien dalam terapi. Pertanyaan yang penting adalah, "Apa yang terbaik bagi orang tertentu?" Praktisi harus berupaya berhati-hati untuk menentukan secara tepat apa hubungan dan apa strategi pengobatan akan bekerja baik dengan klien masing-masing dan di mana keadaan. Asumsi yang mendasari pendekatan ini adalah bahwa karena individu-individu dipengaruhi oleh berbagai masalah tertentu, adalah tepat bahwa banyak kedua strategi pengobatan dan gaya terapi berbeda yang digunakan dalam membawa perubahan. Terapi fleksibilitas dan fleksibilitas, bersama dengan luas lebih dari kedalaman, dianggap berada dalam orientasi multimodal.

\section{Cognitive-Behavior Therapy}

Kebanyakan terapi kontemporer dapat dianggap "kognitif," dalam pengertian umum, karena mereka memiliki tujuan untuk mengubah pandangan subjektif klien 'dari diri mereka sendiri dan dunia. Namun, pendekatan kognitif-perilaku berbeda dari kedua terapi psikodinamik dan pengalaman dalam bahwa fokus utama dari Terapi Kognitif-Perilaku (CBT) adalah asumsi kedua adalah klien salah dan merusak kepercayaan dan pengajaran mengatasi keterampilan yang dibutuhkan untuk menangani masalah mereka.

Dalam banyak hal, perilaku terapi rasional emotif (REBT) dapat dianggap sebagai praktek yang baik untuk terapi komprehensif dan eklektik. teknik kognitif, emotif, dan perilaku Banyak dapat digunakan

Insight : Jurnal Bimbingan Konseling Volume 5(2) dalam mengubah seseorang emosi dan perilaku dengan mengubah struktur kognisi seseorang. REBT terbuka untuk prosedur penggunaan terapi yang berasal dari sekolah lain, terutama dari terapi perilaku.

Terapi kognitif Aaron Beck yang benar-benar sebuah pendekatan integratif, karena begitu banyak menarik modalitas psikoterapi (Alford \& Beck, 1997). Terapi kognitif berfungsi sebagai jembatan antara terapi psikoanalitik dan terapi perilaku. Terapi kognitif menyediakan, terstruktur terfokus, pendekatan aktif. Ini saham perspektif fenomenologis dunia dalam berurusan dengan klien dengan psikodrama, Adlerian, eksistensial, orang-terpusat, dan terapi Gestalt.

Seorang penulis khususnya fitur nilai dari seluruh terapi cognitivebehavioral (dan terapi feminis) adalah demistifikasi dari proses terapi. Yang berbasis pada model pendidikan, pendekatan ini semua menekankan aliansi kerja antara terapis dan klien. Pendekatan ini mendorong self-help, memberikan umpan balik terus-menerus dari klien pada seberapa baik strategi pengobatan yang bekerja, dan memberikan struktur dan arah proses terapi yang memungkinkan untuk evaluasi hasil. Dalam pendekatan cognitivebehavioral, klien aktif, informasi, dan bertanggung jawab untuk arah terapi karena mereka adalah mitra dalam perusahaan.

\section{Realitas Terapi Dan Teori Pilihan}

Dalam banyak hal, teori pilihan, yang mendasari praktek terapi realitas, yang didasarkan pada premis fenomenologis dan eksistensial. Dari perspektif teori pilihan, klien memilih tujuan mereka dan bertanggung jawab untuk jenis dunia yang mereka ciptakan. Manusia bertanggung jawab atas apa yang mereka pilih untuk lakukan, tidak peduli apa yang telah terjadi di masa lalu. Realitas saham banyak konsep terapi dengan terapi kognitifperilaku.

Salah satu konsep terapi realitas adalah bahwa perilaku dari total, yang membuat 
ini salah satu pendekatan interaktif. Jumlah perilaku mengajarkan bahwa perilaku semua terdiri dari empat komponen yang tidak dapat dipisahkan namun berbeda: bertindak, berpikir, merasakan dan fisiologi. Penekanan utama diberikan untuk bertindak dan berpikir, untuk aspek perilaku total lebih mudah untuk mengubah dari komponen perasaan dan fisiologi. Kunci untuk mengubah perilaku dari total klien terletak dalam memilih untuk mengubah apa yang dia lakukan dan berpikir, karena ini adalah perilaku bahwa seseorang dapat mengontrol. Jika komponen klien melakukan perubahan yang nyata dan berpikir, kemudian merasakan dan komponen fisiologis akan berubah juga (Glasser, 1998, 2000).

Penulis gagasan dasar dari nilai-nilai harus memikul tanggung jawab pribadi untuk perasaan seseorang, yang ditekankan oleh terapi realitas. Teori Pilihan tantangan klien untuk menerima bagian mereka benar menciptakan perasaan mereka. Misalnya, depresi bukanlah sesuatu yang hanya terjadi pada manusia, tetapi sering hasil dari apa yang mereka lakukan dan bagaimana mereka berpikir. Glasser $(1998,2000)$ berbicara tentang depresi atau kemarahan, bukan tertekan atau marah. Dengan perspektif ini, depresi dapat dijelaskan sebagai klien membuat pilihan aktif daripada hasil dari korban pasif. Jelas, penekanan pada teori pilihan adalah bagaimana orang berpikir dan bertindak, dan dalam pengertian ini, saham banyak tema-tema pendekatan kognitifperilaku.

\section{Adlerian Therapy}

Tujuan dasar dari pendekatan Adlerian adalah untuk membantu klien mengidentifikasi dan mengubah keyakinan mereka yang keliru tentang diri kita, orang lain, dan kehidupan dan dengan demikian berpartisipasi lebih lengkap dalam dunia sosial. Proses terapi untuk membantu klien membuat perubahan mendasar dalam gaya hidup mereka, yang menyebabkan perubahan dalam cara mereka merasa dan berperilaku. Dari perspektif Adlerian, terapi adalah usaha koperasi. Terapi diarahkan untuk menantang klien untuk menerjemahkan wawasan mereka ke dalam tindakan di dunia nyata.

Salah satu kekuatan pendekatan
Adlerian adalah dengan melakukan
eklektisisme teknis. Alderian cocok untuk fleksibilitas dalam memenuhi kebutuhan klien yang beragam (Watts, 1999) model. Adlerians tidak terikat untuk mengikuti satu set prosedur yang spesifik, yang memberikan mereka kebebasan yang lebih dalam bekerja dengan klien. terapis Adlerian pandai menggambar pada berbagai teknik kognitif, perilaku, dan pengalaman yang mereka pikir akan bekerja terbaik bagi klien tertentu.

Salah satu kontribusi Adler yang paling penting adalah efeknya pada terapi lain. Banyak ide dasar telah menemukan cara mereka ke sekolah-sekolah psikologis lain, seperti pendekatan keluarga sistem, terapi Gestalt, belajar teori, terapi realitas, terapi perilaku rasional emotif, terapi kognitif, orang-terapi berpusat, dan eksistensialisme. Semua pendekatan ini didasarkan pada konsep yang sama orang sebagai purposive dan mendefinisikan diri mereka sendiri dan berusaha untuk pertumbuhan dan arti dalam hidup.

Perspektif Adlerian bersifat holistik, yang berarti bahwa individu dapat dipahami dengan mempertimbangkan semua aspek fungsi manusia. Teori ini alamat klien masa lalu, sekarang dan masa depan. Gagasan teleologi, atau perjuangan untuk makna dan tujuan, adalah konsep pusat. Konsep kepentingan sosial adalah salah satu yang bisa menjadi dasar dari setiap sistem teoritis. Prinsip ini menyiratkan bahwa orang memiliki kebutuhan untuk berkontribusi untuk membuat dunia menjadi tempat yang lebih baik. bunga Sosial menyiratkan akan melampaui diri mereka sendiri dan terlibat dalam membuat perbedaan dalam kehidupan orang lain. bunga Sosial melibatkan menemukan makna hidup dengan memperluas luar perbaikan diri. 
Teori kontemporer Adlerian yang berharga dalam arti bahwa itu adalah pendekatan integratif. Teori merupakan integrasi dari kognitif, psikodinamik dan perspektif sistem, dan dalam banyak hal, menyerupai teori konstruksionis sosial. Teori konstruksionis sosial kontemporer atau terapi konstruktivis, ditumbuk saham biasa dengan pendekatan Adlerian. Beberapa fitur umum termasuk: penekanan pada pembangunan yang ramah klien/ hubungan terapis, penekanan pada kekuatan klien, sumber daya dan bimbingan di masa mendatang optimis (Watts, 1999, Watts \& Carlson, 1999) .

\section{Feminist and Systemic Therapy}

Terapi feminis biasanya terapi relatif jangka pendek yang bertujuan pada perubahan individu dan sosial. Tujuannya adalah untuk menggantikan kesadaran feminis saat ini patriarkal dan menciptakan suatu masyarakat yang menghargai kesetaraan dalam hubungan, menekankan saling ketergantungan bukan ketergantungan, dan mendorong perempuan untuk mendefinisikan diri mereka daripada didefinisikan oleh tuntutan sosial.

Terapis feminis berkomitmen untuk aktif memecah hirarki kekuasaan dalam hubungan terapeutik melalui penggunaan berbagai intervensi. Beberapa strategi yang unik untuk terapi feminis, seperti analisis jender-peran dan respons, analisis kekuatan dan intervensi, dengan asumsi posisi bek menantang sikap konvensional peran yang sesuai untuk perempuan dan mendorong pelanggan untuk mengambil tindakan sosial. Terapis dengan orientasi feminis untuk memahami betapa pentingnya menjadi sadar akan peran pelanggan khas telah disosialisasikan dengan, dan terampil dalam membantu klien mengidentifikasi dan menantang pesan ini.

Terapis feminis juga meminjam strategi terapi untuk berbagai model terapi. Beberapa intervensi ini meliputi peran, bibliotherapy, pelatihan ketegasan, latihan perilaku, restrukturisasi kognitif, psychodramatic teknis, mengidentifikasi dan menantang menulis keyakinan belum diuji dan jurnal. prinsip terapi feminis dan teknik dapat digunakan untuk berbagai modalitas terapi seperti terapi individual, konseling pasangan, terapi keluarga, konseling kelompok dan keterlibatan masyarakat.

Feminis dan terapi sistemik didasarkan pada asumsi bahwa individu-individu yang paling baik dipahami dalam konteks hubungan. teori tradisional Sebagian besar konseling tidak menempatkan penekanan pada peran faktor sistemik dalam mempengaruhi individu. Namun, terapi feminis dan sistemik beroperasi pada premis bahwa masalah individu tidak dapat dipahami dengan berfokus pada dinamika internal pelanggan. Perilaku disfungsional kesatuan menembak individu interaksional dari keluarga, masyarakat dan sistem sosial. Dengan demikian, solusi untuk masalah individu harus dirancang dalam perspektif kontekstual.

Pendekatan integratif penulis meminjam konsep pendekatan feminis, sistemik, dan multikultural - yang menambah dimensi penting untuk memahami lebih baik bagaimana individu bisa mengubah dunia mereka dengan menyesuaikan internal dan eksternal. Pendekatan Integratif melibatkan mengobati penulis sistemik (keluarga, masyarakat, budaya) masalah variabel berdasarkan yang berkontribusi terhadap seseorang.

\section{Kesimpulan}

Pembaca diminta untuk mengingat bahwa merancang pendekatan integratif untuk konseling membutuhkan waktu, refleksi, dan praktek. Dalam mengembangkan pendekatan terapeutik, pembaca didorong untuk terlibat dalam membaca program. Membaca adalah cara yang realistis dan berguna untuk memperluas basis pengetahuan seseorang dan untuk menyediakan satu dengan ideide tentang cara membuat, menerapkan, dan mengevaluasi teknik. Pembaca juga dianjurkan 
untuk menghadiri lokakarya dan terbuka untuk ide-ide yang tampaknya memiliki arti khusus bagi mereka dan yang sesuai dengan konteks dari pekerjaan mereka. Sebelum mengadopsi ide dari berbagai model terapi, sangat penting untuk secara kritis mengevaluasi ide-ide dan menerapkan mereka secara pribadi. Penulis merekomendasikan bahwa konselor bereksperimen dengan berbagai teknik terapi yang berbeda, tetapi hindari menggunakan teknik ini dalam metode kaku atau memasak. Teknik-teknik tersebut hanya alat untuk membantu para praktisi untuk secara efektif menjangkau pelanggan mereka. Pembaca akan melakukannya dengan baik untuk menyesuaikan teknik mereka sehingga mereka mengambil kepribadian dan gaya mereka sendiri, dan pada saat yang sama, akan sangat membantu untuk terbuka untuk umpan balik pelanggan pada seberapa baik teknik-teknik bekerja untuk mereka.

Konselor akan melakukannya dengan baik untuk mempertimbangkan gaya pribadi mereka sendiri dalam proses mengembangkan pendekatan integratif mereka. Seni konseling integratif menyiratkan bahwa tidak ada model prefabrikasi yang sempurna sesuai setiap praktisi. Sebaliknya, tantangannya adalah untuk konseling menyesuaikan pendekatan yang disesuaikan dengan masing-masing praktisi.

\section{DAFTAR PUSTAKA}

Alford, B. A., \& Beck, A. T. (1997). The integrative power of cognitive therapy. New York: Guilford Press.

Corey, G. (2001a). The art of integrative counseling. Pacific Grove, CA: Brooks/Cole.

Corey, G. (2001b). Case approach to counseling and psychotherapy (5th ed). Pacific Grove, CA: Brooks/Cole.

Corey, G. (2004). Theory and practice of group counseling (6th ed.). Belmont, CA: Brooks/
Cole-Thomson Learning.

Corey, G. (2005). Theory and practice of counseling psychotherapy (International student ed.). Belmot, CA: Brooks/Cole-Thomson Learning. 